\title{
Flood Modeling on Koya Catchment Area Using Hyfran, Web Map Service, and HEC-RAS Software
}

\author{
Anwer H. Dawood ${ }^{1,2}$, Dana K. Mawlood ${ }^{1}$, Nadhir Al-Ansari ${ }^{3}$ \\ ${ }^{1}$ Department of Civil Engineering, College of Engineering, Salahaddin University-Erbil, \\ Kurdistan Region - F.R. Iraq \\ ${ }^{2}$ Department of Geotechnical Engineering, Faculty of Engineering, Koya KOY45, \\ Kurdistan Region - F.R. Iraq \\ ${ }^{3}$ Department of Civil, Environmental and Natural Resources Engineering, Lulea University of Technology, \\ Lulea, Sweden
}

\begin{abstract}
This research uses a new engineering approach in the management of rainfall storms in the Koya basin to delineate the inundation boundaries for the floods that occur in the study area. This covers some agricultural lands and residential areas in the countryside. According to this approach, it is possible to determine the best sites for building small dams and water collection basins for water harvesting. The above-mentioned approach consists of a meteorological and morphological study, soil classification, flood hydrograph modeling, and demarcation of inundation boundaries, to find the depth and velocity of flood flow. The average runoff depth was based on curve number (CN) values. These values were determined based on soil cover types and soil class according to the Harmonized World Soil Database program. Accordingly, the soil class in the study area is Group B alluvial silt and the $C N$ value is determined to be 71 . The results showed that the runoff potential varied with land use and soil characteristics. Hydrological modeling is performed by HECHMS software (Army Corps of Engineers Hydrologic Engineering Center - Hydrologic Modeling System), which simulates runoff precipitation process using a SCS Soil Conservation service $\mathbf{C N}$ model. A flood hydrograph generates at the catchment area outlet, and the delineation of the floodplains is verified by HEC-RAS software (US Army Corps of Engineers Hydrologic Engineering Center-River Analysis System). Furthermore, the results showed that the flood return period of 100 years could reach sensitive areas such as urban, agricultural, and residential areas. According to the results of this study, there were suitable sites in the catchment area for the establishment of small dams and ponds for water harvesting.
\end{abstract}

Index Terms - Catchment area management; Flood delineation; Flood modeling; Hydrologic process; Hyfran and Web Map Service software.

ARO-The Scientific Journal of Koya University

Vol. IX, No.2 (2021), Article ID: ARO.10824, 5 pages

DOI: $10.14500 /$ aro. 10824

Received: 01 June 2021; Accepted: 15 December 2021

Regular research paper: Published: 25 December 2021

Corresponding author's email: anwer.hazim@koyauniversity.org

Copyright (C) 2021 Anwer H. Dawood, Dana K. Mawlood, Nadhir Al-

Ansari. . This is an open access article distributed under the Creative

Commons Attribution License.

\section{INTRODUCTION}

Water is one of the most important natural resources for countries and a fundamental basis for their growth and development. In the same time, flooding is one of the most devastating natural disasters on the planet. Floods take place due to extensive rainfall in short time duration, incorrect land use, and deforestation in headwater zones (Abdelshafy, et al., 2020). Various parts of the world are at risk of flooding, causing great loss of life and property. These large losses resulting from natural hazards such as floods are the main impetus for research, investigation, and scientific understanding of the nature of flooding and the resulting wastes. This indicates that natural hazards are a challenge. Since floods threaten life and the environment, which made researchers in dire need to find and choose the best ways, methods and procedures to protect humans and environment through such hydrological study to indicate the flood risk area and safe area for planning of urban extension. In addition, protection measures can turn the equation by converting the flood from a disaster to blessing through building infrastructure projects for flood utilization, water storage, and reuse in the dry season.

The studied area is located in East of Erbil province and west of Dokan district. It is approximately $70 \mathrm{~km}$ from Erbil (the capital of Kurdistan region), approximately and $50 \mathrm{~km}$ from Dokan, the Koya city (latitude $3605 \mathrm{~N}$, longitude 44 37E, altitude 610M) (Fig. 1). The climate of the study area is classified as arid and semi-arid region.

\section{Methodology}

To get the maximum storm rainfall depth value, rainfall daily data were obtained from Koya meteorology station and were statistically analyzed using the model proposed by Hyfran Plus software, and then, the morphological study was carried out using geographic information system (GIS), Web Map Service (WMS), Global Mapper, and Google Earth for the determination of the boundary of the catchment area. 
The next step was runoff calculations which were carried out using the curve number (CN)-SCS model, Harmonized World Soil Database (HWSD) Viewer, HEC-HMS for Soil classification, and Determination of Peak flow according to SCS-CN. The final step was using the HEC-RAS model for drawing the flood plain.

\section{Results AND Discussion}

\section{A. Maximum Daily Rainfall Through the Year}

The rainfall maximum daily data are available from 2001 to 2021 for Koya station. Table I shows the maximum daily rainfall data in Koya station.

For planning and design purposes of various hydrological projects, the best fit of rainfall data is used (Khalid, et al., 2016). For this purpose, the available data for the study area were treated statistically for return period (2-200) years using different methods to find the maximum daily rainfall storm depth as shown in Table II (Kurdistan Regional Government, Ministry of Agriculture and Water Resources, Directorate of Koya Irrigation; Directorate of Koya Agriculture, 2021, rainfall data).

To describe the amount of daily rainfall data, it is necessary to identify the distribution which is the best fit of the data. This was achieved using different statistical methods such as exponential distribution, GEV generalized extreme value distribution, normal distribution, lognormal distribution, and gamma distribution methods. The results are tabulated in Table III.

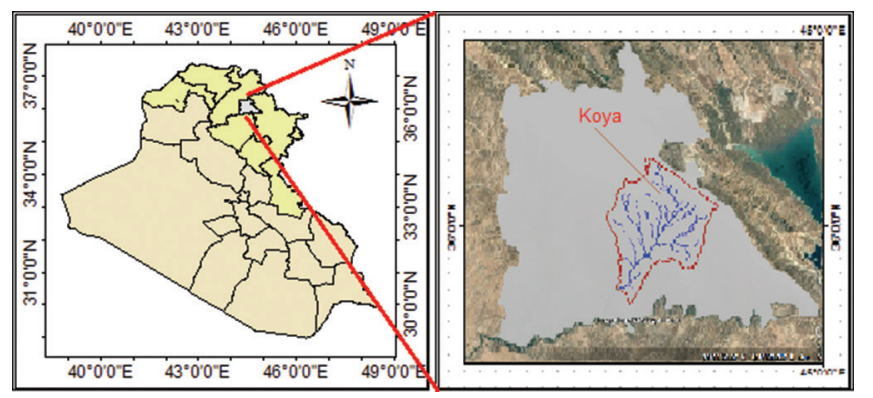

Fig. 1. Location map of study area Koya basin.

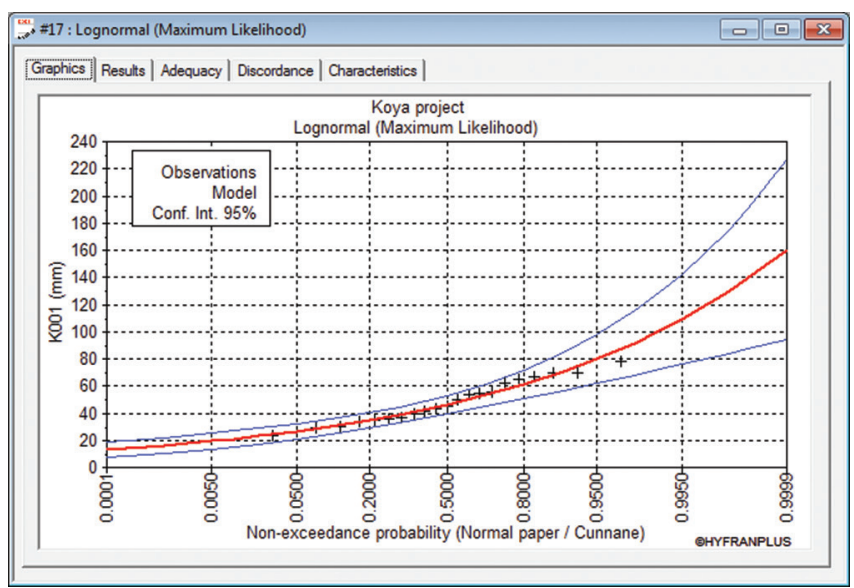

Fig. 2. Probability distribution curve of Koya basin using lognormal distribution.
According to the tests, the best distribution is one when lognormal method was used (Chow, et al., 1988). Accordingly, when the data given in Table II were used, the results of the maximum rainfall data at different return periods in Table II lognormal distribution daily rainfall data were obtained, as shown in Fig. 2.

\section{B. Morphological Study}

Physical parameters of the catchment area are very significant for hydrological study such as length of longest flow path and mean slope. Using DEM $30 \mathrm{~m}$ accuracy by global mapper for the study area and drawing the boundary of the catchment, the catchment characteristics were determined using WMS (Al Kalbani, 2021) (Table IV and Fig. 3).

\section{Runoff Calculations Using SCS-CN Model}

One of the most common techniques model of SCS-CN is for the measurement of amount of direct surface runoff for a given period during a rainfall event. The SCS model is an

TABLE I

Maximum Daily Rainfall Depth Record in Koya station

\begin{tabular}{lccc}
\hline \hline Year & Max. daily $(\mathrm{mm})$ & Year & Max. daily $(\mathrm{mm})$ \\
\hline 2001 & 35.5 & 2012 & 70 \\
2002 & 55.5 & 2013 & 78.5 \\
2003 & 70 & 2014 & 35 \\
2004 & 65 & 2015 & 36.5 \\
2005 & 55 & 2016 & 29.3 \\
2006 & 40 & 2017 & 54 \\
2007 & 50 & 2018 & 66.6 \\
2008 & 30 & 2019 & 45 \\
2009 & 33.5 & 2020 & 43 \\
2010 & 62 & 2021 & 23.6 \\
2011 & 41 & & \\
\hline \hline
\end{tabular}

TABLE II

Design Storm Depth Resulting from Statistical Analysis of Maximum Daily Rainfall Record Using Serval Distribution Methods

\begin{tabular}{lcccccc}
\hline \hline \multicolumn{6}{c}{ Predicted design storm resulted from Hyfran } & \multirow{2}{*}{ Graphical } \\
\cline { 1 - 6 } Dist. & Exp. & GEV & Normal & Lognormal & Gamma & \\
\cline { 1 - 5 } Return period (Year) & & & & & & \\
2 & 40.5 & 47.4 & 48.5 & 46.1 & 46.9 & 44.2 \\
5 & 64.5 & 60.8 & 61.8 & 61.1 & 60.9 & 61.0 \\
10 & 82.6 & 68.3 & 68.7 & 70.8 & 69.2 & 73.8 \\
25 & 107 & 76.4 & 76.1 & 82.9 & 78.8 & 90.6 \\
50 & 125 & 81.6 & 80.8 & 91.7 & 85.5 & 103.3 \\
100 & 143 & 86.2 & 85.1 & 101 & 91.7 & 116.1 \\
200 & 161 & 90.2 & 89.1 & 109 & 97.7 & 128.8 \\
\hline \hline
\end{tabular}

Where: Exp.=Exponential distribution, $\mathrm{GEV}=$ General extreme value distribution, Normal=Normal distribution, Lognormal=Lognormal distribution, Gamma=Gamma distribution
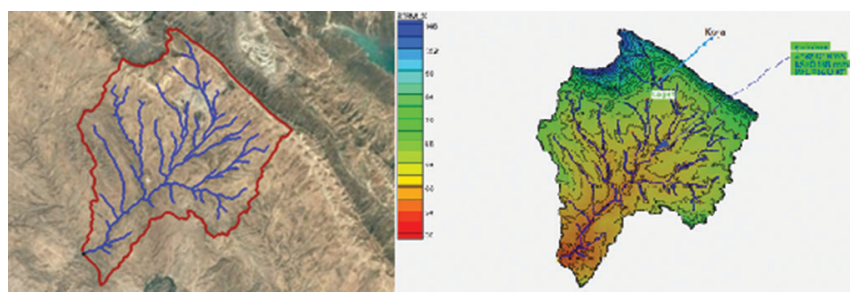

Fig. 3. Koya catchment area boundary with drainage lines. 
empirical model and only includes a single parameter, the $\mathrm{CN}$, which incorporates the hydrological effects of land use (Ara and Zakwan, 2018).

To apply the model, the following data required for this model: Catchment area in $\mathrm{Km}^{2}$, calculate the time of concentration in hours, $\mathrm{CN}$, and maximum daily rainfall depth in mm through return period (Sc, 1986).

The main challenge of hydrology in estimating the volume of surface runoff is how to estimate the surface runoff coefficient resulting from an effective rainfall storm in basins where no measurement stations are available. The surface runoff curve $(\mathrm{CN})$ is a major factor in determining the runoff in the SCS hypothesis, which takes into account land use, soil type, geological structure, vegetation, and rainfall (USDA-SCS, 1972).

According to the HWSD viewer, the soil type in the studied area is divided into two zones which are loam and light loam so the soil class is type B silt loam or loam (Harmonized World Soil Database - HWSD - 2021).

Now for determining $\mathrm{CN}$, the check land use is to be checked, so the best description for the study area it is: Oakaspen - mountain brush mixture of oak brush, aspen, mountain mahogany, bitter brush, and other brush, plus the urban developed area in Koya city and villages. Runoff CNs for arid and semi-arid rangelands and hydrologic condition are poor so the best $\mathrm{CN}$ for class B is 71 (Sc, 1986) (Figs. 4 and 5).

According to the information of classification land use bare land and urban area, soil type it is considered as silt loam Group B, hydrologic condition poor.

Based on the above results, the SCS $\mathrm{CN}$ is 71 for the catchment area.
SCS runoff equation:

$$
\mathrm{Q}=\frac{(P-I a)^{2}}{(P-I a)+S}
$$

Where

$\mathrm{Q}=$ Runoff $(\mathrm{mm})$

$\mathrm{P}=$ Rainfall $(\mathrm{mm})$

$\mathrm{S}=$ Potential maximum retention after runoff begins $(\mathrm{mm})$ and

$\mathrm{Ia}=$ Initial abstraction $(\mathrm{mm})$

$\mathrm{Ia}=0.2 \mathrm{~S}$

$$
\begin{aligned}
& \mathrm{Q}=\frac{(P-0.2 \mathrm{~S})^{2}}{(P+0.8 \mathrm{~S})} \\
& \mathrm{S}=\frac{1000}{\mathrm{CN}}-10
\end{aligned}
$$

(4) (USDA-SCS, 1972).

$\mathrm{CN}=$ Curve number: Unitless number has range $(0-100)$ depend on the soil group, land use, and land cover, and determinate from table provided by the SCS (USDA-SCS, 1972).

\section{Hydrological Modeling}

As a start, the catchment is to be analyzed using HEC-HMS Hydrologic Engineering Center, Hydrologic Modeling System (Gebre, 2015; Scharffenberg, et al., 2010) and then for more accuracy analysis of the catchment will be divided to number of sub-catchments as shown in Fig. 6.

The modeling method was used in the program HEC-HMS for 100-year return period for drawing outlet Hydrograph at end of catchment area. Now, the runoff data were used by

\begin{tabular}{|c|c|c|c|c|c|c|c|}
\hline \multicolumn{6}{|c|}{ Statistical distribution methods } & \multirow[t]{2}{*}{ Criterion for success } & \multirow[t]{2}{*}{ Best method } \\
\hline Test name & Exp. & GEV & Normal & Lognormal & Gamma & & \\
\hline Chi-squared & 5.00 & 2.71 & 3.86 & 2.71 & 3.29 & Min. & GEV, Lognormal \\
\hline RMSE & 19.29 & 21.03 & 21.7 & 10.86 & 17.09 & Min. & Lognormal \\
\hline Nash & 0.769 & 0.973 & 0.970 & 0.998 & 0.989 & Max. & Lognormal \\
\hline
\end{tabular}

TABLE III

Goodness of Fit Results for Different Distribution Methods

Where: Chi-squared=Chi-squared goodness of fit test, RMSE=Root mean square error test, IOA=Index of agreement test, Nash=Nash-Sutcliffe coefficients test

\begin{tabular}{|c|c|c|c|c|c|}
\hline Area $\mathrm{km}^{2}$ & Perimeter km & Mean slope & Longest flow path km & Highest El. & Lowest El. \\
\hline 324.27 & 121.66 & 0.1136 & 35.2 & 975 & 309 \\
\hline
\end{tabular}

TABLE IV

Koya Catchment Area Characteristics

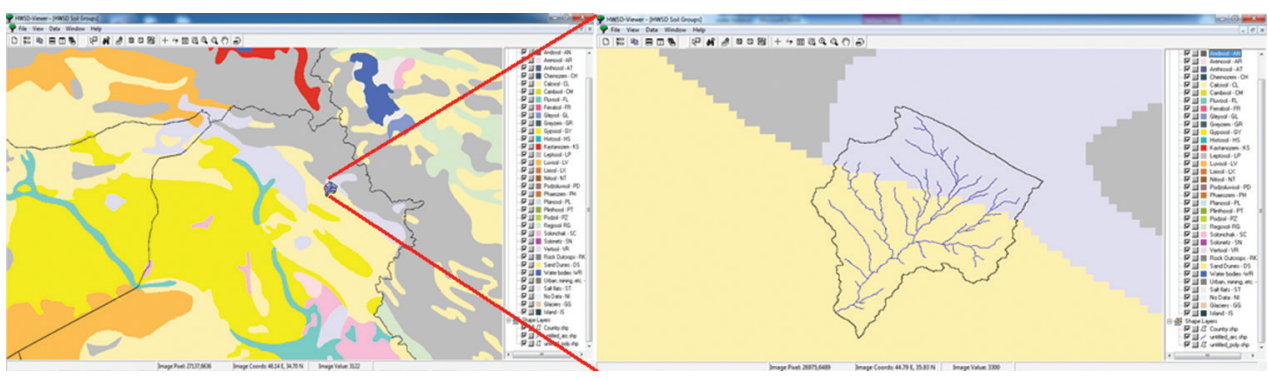

Fig. 4. Study area soil class location by Harmonized World Soil Database viewer. 


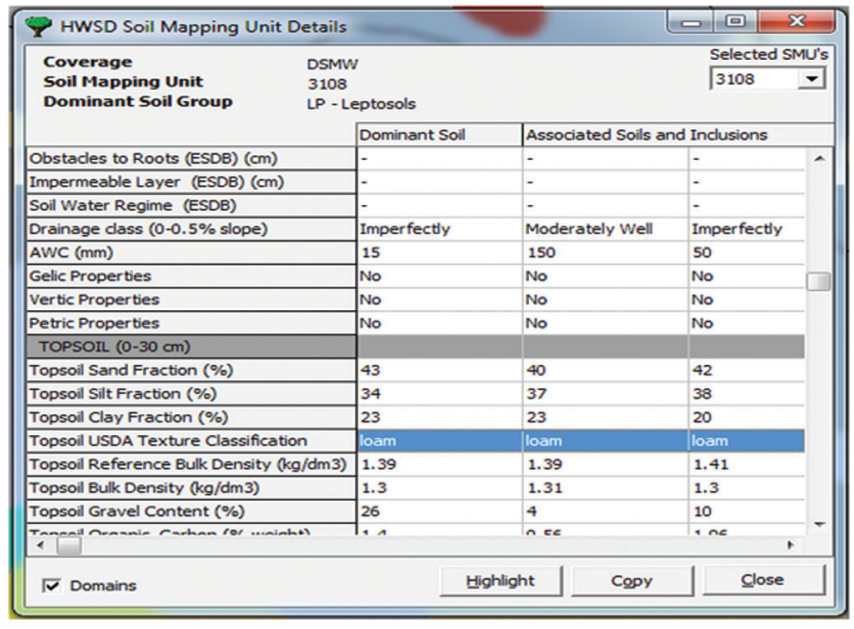

Fig. 5. Study area soil class properties by Harmonized World Soil Database viewer.
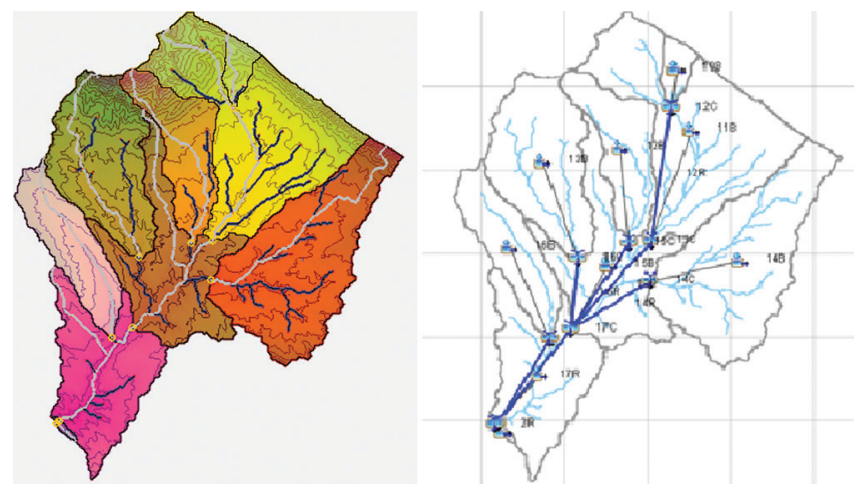

Fig. 6. Dividing catchment area by HEC-HMS Hydrologic Engineering Center, Hydrologic Modeling System into eight subcatchments.

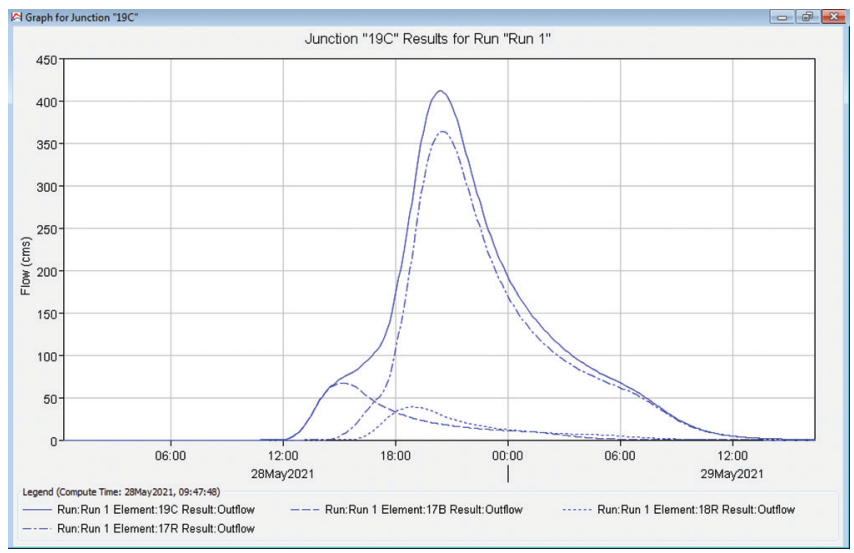

Fig. 7. Outlet subcatchment hydrographs created by HEC-HMS for 100-year return period.

Hec-Ras 5.07 (Hydrologic Engineering Center, River Analysis system) software for flood modeling. This program is capable of modeling water basins, drawing flood boundaries, flood depth, and flow velocity. Thus, the necessary precautions can be taken to determine the areas to which the flood reaches, to evacuate activities and projects before the flood occurs. The plan that was followed in this research to model the flooding of the Koya basin was to download a digital elevation model using the GIS program for the Koya area with an accuracy of

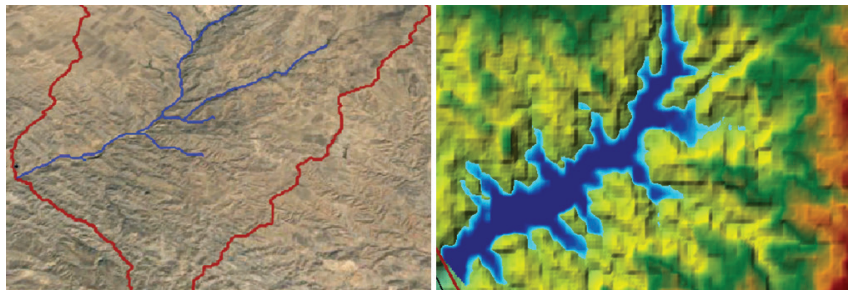

Fig. 8. Flood waters depth and flooded areas simulated by HEC-RAS model for 100-year flood event in Koya basin stream.

up to $5 \mathrm{~m}$. Then, the area of the catchment and the paths of the valleys were determined using Global Mapper and WMS programs. Finally, the completed model was transferred to the Hec-Ras program (Salajegheh, et al., 2009) where the data were processed and the flood graph, whose frequency is 100 years, was drawn. The modeling of eight subcatchments flow is shown in Fig. 7.

\section{E. Flood Modeling}

According to the procedure of hydrological modeling explained in (Tate, 1999) Floodplain Mapping Using HECRAS and ArcView GIS, flood modeling by HEC-RAS model has been done with depth of rainfall for return period every 100 year, and the result shows the flood plain area are cover agriculture and urban area, as shown in Fig. 8.

\section{CONCLUSION}

The morphological characteristics of the Koya basin using WMS and Global Mapper program indicated that the basin contributed significantly to the floods, due to the increase in the value of the $\mathrm{CN}$ as a result of the increase in the urban area, the decrease in vegetation cover, and the change of land uses. The value of the CN 71 was found adjusted according to the type of soil and land use. The rainfall runoff was simulated using the CN SCS model. Flood hydrography was investigated in the process of delimitation of floodplains by the Hec-Ras model. These results showed that a 100-year return period flood more than $420 \mathrm{~m}^{3} / \mathrm{s}$ can invade critical areas such as urban area (villages), agricultural area, and public roads in the outlet of the catchment.

This study is very important in the decision-making process for the local authority so that they can benefit from the results in applying measures for the economic and social development of the Koya catchment.

The study shows that the measured water flow and volume can be stored in ponds by building small dams on the valley streams for water harvesting. The model can be further utilized to predict water storage based on precipitation and evapotranspiration results.

\section{ACKNOWLEDGMENTS}

The authors would like to thank the Kurdistan Regional Government Ministry of Agriculture and Water Resources, Directorate of Koya Irrigation, Directorate of Koya Agriculture for their 
Support and providing rainfall data, where their support is highly appreciated.

\section{REFERENCES}

Abdelshafy, M., Mostafa, A. and Seleem, E.M., 2020. Flash Flood modeling on wadi reem in the Western Region, Kingdom of Saudi Arabia. Journal of the Egyptian Academy of Environmental Development, 21(1), pp.11-24.

Al Kalbani, K., 2021. 3D city model for monitoring flash flood risks in Salalah, Oman. International Journal of Engineering and Geosciences, 7(1), 17-23.

Ara, Z. and Zakwan, M., 2018. Estimating runoff using SCS curve number method. International Journal of Emerging Technology and Advanced Engineering, 8(5), 195-200.

Chow, V. Te, Maidment, D. R., \& Mays, L. W. (1988). Applied Hydrology. McGraw Hill, Inc., New York.

Gebre, S.L., 2015. Application of the HEC-HMS model for runoff simulation of upper Blue Nile River Basin. Journal of Waste Water Treatment and Analysis, 6, 2.

Harmonized World Soil Database, 2021. Land and Water Food and Agriculture Organization of the United Nations Land and Water Food and Agriculture Organization of the United Nations. Available from: https://iiasa.ac.at/web/home/ research/researchPrograms/water/HWSD.html. [Last accessed on 2021 Dec 22].

Khalid, K., Alib, M.F., Manc, N.F., Rahmanb, N.F.A., Yaccob, A.A., Noor, N.A.M. and Rosli, S.H., 2016. Rainfall data analysis in langat river basin using hyfranplus. Journal of Engineering and Applied Sciences, 11(11), 2360-2365.

Kurdistan Regional Government, 2021 Ministry of Agriculture and Water Resources, Directorate of Koya Irrigation, Rainfall Data, Kurdistan Regional Government.

Kurdistan Regional Government, 2021 Ministry of Agriculture and Water Resources, Directorate of Koya Agriculture, Rainfall Data, Kurdistan Regional Government.

Salajegheh, A., Bakhshaei, M., Chavoshi, S. and Hajivar, M.N., 2009. Floodplain mapping using HEC-RAS and GIS in semi-arid regions of Iran. Desert (Biaban), 14(1), 83-93.

Sc, 1986. Urban Hydrology for Small. Soil Conservation, Technical Release, 55 (TR-55), No. 164. Available from: https://www.nrcs.usda.gov/Internet/ FSE_DOCUMENTS/stelprdb1044171.pdf

Scharffenberg, W., Ely, P., Daly, S., Fleming, M. and Pak, J., 2010. Hydrologic Modeling System (Hec-Hms): Physically-Based Simulation Components. $2^{\text {nd }}$ Joint Federal Interagency Conference, No. 8.

Tate, E.C., 1999. Floodplain Mapping Using HEC-RAS and ArcView GIS. Technical Report University of Texas at Austin, Center for Research in Water Resources.

USDA-SCS, 1972. Part 630 Hydrology National Engineering Handbook Chapter 10 Estimation of Direct Runoff from Storm Rainfall, National Engineering Handbook. 